\title{
Exploration on the Cultivation of Interior Design Talents in Ethnic Minority Regions
}

\author{
Jing Guo ${ }^{1}$ Zhao $\mathrm{Xu}^{1, *}$ \\ ${ }^{1}$ Art and Design College, Southwest Forestry University, Kunming, Yunnan 650224, China \\ *Corresponding author. Email: 691435551@qq.com
}

\begin{abstract}
Against the background of implementing the strategy of rural revitalization, China is vigorously improving the rural human settlement environment, constructing livable and beautiful villages, promoting rural residential, bed and breakfast, hotel and other interior design projects. However, high-quality interior design talents with ethnic cultural literacy are relatively scarce, which is an urgent task for the current vacancy in the interior design market in ethnic minority areas. The article analyzes the problems existing in the interior design market in ethnic minority areas, and proposes that students should be cultivated to establish a systematic concept of interior design, explore the diverse ethnic cultures of ethnic minority areas, and cultivate students' innovative awareness and social practice capabilities in order to improve the overall level of interior design talents, so as to lay a solid foundation for the steady implementation of the rural revitalization strategy in minority areas, improve the quality of rural human settlements, and adapt to the sustainable development of the national economy, society and environment
\end{abstract}

Keywords: Ethnic minority areas, Interior design, Ethnic culture, Talent cultivation.

\section{INTRODUCTION}

In recent years, China has vigorously promoted the construction of rural human settlements and the construction of livable and beautiful villages, and implemented the construction projects of minority villages and villages. In 2014, 340 characteristic villages in the first batch were named as "Chinese Minority Characteristic Villages" by the National Ethnic Affairs Commission. After years of government support and assistance, villages in ethnic minority areas rely on good regional characteristics and natural resources to build a number of comprehensive demonstration villages for rural revitalization, ethnic characteristic tourist villages and traditional villages with good ecology, beautiful environment and strong cultural atmosphere. And they combined the rich cultural heritage of ethnic minorities and the simple and beautiful village scenery to promote the interior design projects of residential dwellings, homestays

*Project: 2020 Southwest Forestry University Educational Science Research Key Project Funding Project "Research and Practice on the Cultivation Model of Top Innovative Talents in Environmental Design" (ZD202002). and hotels. China is in a period of rapid development of science, technology, economy, and culture. People in minority areas have put forward higher requirements for the quality of living and living environment in terms of cleanliness, health, comfort, and beauty. However, due to the differences in the living habits, behavioral characteristics, language expression, regional environment and culture of ethnic minority groups, designers should not equate interior design projects in ethnic minority areas with general interior design projects in the process of designing ethnic minority village dwellings, homestays, hotels, etc., which puts forward higher requirements for interior designers in minority areas.

Therefore, in the work of vigorously promoting the construction of rural human settlements, ethnic minority areas need a group of high-quality interior design talents with ethnic cultural heritage to meet the design tasks of ethnic minority characteristic villages and villages, and how to cultivate interior design talents that have the awareness of inheriting ethnic culture have become a top priority to solve the current vacancies in the interior design market in ethnic minority areas. A qualified professional 
interior designer in ethnic minority areas should have the following capabilities:

- Mastering a wealth of basic knowledge and techniques such as interior design methods, interior decoration materials, renderings, etc., familiar with the design process of each stage of interior design, and having the ability to flexibly apply relevant knowledge to interior design projects;

- Possessing a profound cultural accomplishment, being able to extensively explore various knowledge and information in the project, and being capable to consciously accumulate knowledge to enhance the ability of design cognition and taste;

- Owning the courage and keen insight ability of ethnic minorities' living habits, behavior characteristics, folk customs and religious festivals;

- Understanding the relevant knowledge of furniture supplies, living utensils, and ethnic ornaments in various ethnic spaces, and being good at coordinating and matching various ethnic ornaments;

- Acquiring the ability to appreciate various ethnic minority characteristic indoor spaces, ethnic handicrafts and ornaments;

- Mastering the ability to extract ethnic minority elements, symbols, and color characteristics, and be able to flexibly use ethnic minority characteristic elements, and symbols to decorate indoor spaces with colors;

- Having common sense of various construction techniques and construction techniques, and the ability to evaluate prices.

\section{ESTABLISHING A SYSTEMATIC CONCEPT OF INTERIOR DESIGN}

The system view of interior design is a scientific methodology. Through the collection, analysis and optimization of design information and design elements, people finally decide a set of design schemes that can meet people's high-quality life needs, and then through design, construction, soft decoration and other technological means, they can obtain a high-quality indoor environment [1]. Interior design is a huge system that can be decomposed into three parts: knowledge dimension, time dimension and logical dimension. The knowledge dimensions of interior design include ethnology, aesthetics, feng shui, design, sociology, physiology, psychology, color science, ergonomics, architecture, materials science, acoustics, optics, economics, management and many other disciplines; the time dimension of interior design includes design preparation stage, design analysis stage, scheme design stage, design construction stage, design optimization stage, soft decoration configuration stage, and design evaluation stage. Each stage requires designers to seriously consider the details of the implementation process; the logical dimensions of interior design include investigation of the status quo of interior design projects, analysis of research data, clarification of problems and solutions, preliminary plans, optimization plans, decision-making plans, and implementation plans. Each design link is closely linked to ensure the optimal quality of the design.

In addition, in order to meet the balanced relationship between the local ethnic characteristics and the needs of users, realize the nationalization, comfort, environmental protection and health of the indoor space, interior designers must uphold the concept of inheriting ethnic minority cultures and pay attention to the construction of ethnic minority cultural connotations. They need to reasonably choose furniture and accessories with ethnic characteristics, patterns, colors, and materials according to the size and shape of the indoor space and the living habits, behavior characteristics, folk customs, religious beliefs, hobbies, and economic conditions of ethnic minority residents, so that the indoor environment has obvious ethnic style trends and individual characteristics, and conveys the contemporary ethnic minority's emotional appeals for taste, interest, and preferences.

In short, when cultivating students with the ability to complete interior design in ethnic areas, it is necessary to pay attention to establishing an overall system concept in the interior design process, strengthen the extraction and use of ethnic minority cultural connotations, reasonably control the balance between the local ethnic characteristics and the needs of users, and make overall consideration of many aspects on the premise that the ethnic minority indoor space shows the ethnic characteristics.

\section{EXPLORING THE DIVERSE ETHNIC CULTURE IN ETHNIC MINORITY AREAS}

Yunnan is the province with the largest number of ethnic minorities, and its ethnic culture is 
characterized by diversity. First of all, the distribution of ethnic minorities changes with the geographical environment, topography and landforms. The distribution of ethnic minorities presents the characteristics of large mixed settlements and small gatherings. They take villages as their settlements, and there are also a few villages living together with many ethnic groups. Such a wide distribution and settlement mode will inevitably bring the diversity of ethnic minority cultures and the diversity of their architecture and indoor space forms. Among the Yi people's dwellings, the housing form of the Yi people in the mountainous area of northwestern Yunnan is a wooden house; the housing form of the Yi people in the dry-hot area of southern Yunnan is a soil house; and the housing form of the Yi people in the Pingba area of central Yunnan is a stamp. [2]. It can be seen that due to the different geographical location, climatic conditions, ethnic distribution and settlement patterns of the same ethnic group, the houses that they live in are different, and the forms of interior decoration will also show diversified forms. Secondly, even with the same geographical location and climatic conditions, the housing forms of different ethnic groups are similar, but their housing will also cause a big difference between the plane form and layout and interior decoration of the folk houses due to the different lifestyles, religious beliefs, and aesthetic concepts of each ethnic group. For example, the houses of the Dai and Aini people are bamboo buildings in Xishuangbanna, but because of their different living customs, the Dai people's bedroom is not separated for men and women, while the Aini people have separate rooms for men and women. Adult children live in small houses. The layout is very different, and the content and methods of interior design are also various. Thirdly, the national culture of minority areas is the soul to grasp the nationality of interior design. For example, the Yi people's torch festival culture, tiger culture, October solar calendar and unearthed cultural relics all have profound cultural connotations. Experience and excavation of these cultural connotation carriers can make the designers obtain inspiration for interior design and furniture decoration.

Therefore, to become an excellent interior designer in ethnic minority areas requires personal experience and in-depth exploration of the diverse ethnic cultures of ethnic minority areas, as well as a deep understanding of the architectural forms, construction techniques, spatial patterns, components, forms, symbols, materials, colors, etc. of various ethnic groups due to different geographical environments, climatic conditions, lifestyles, religious beliefs, festival customs, and aesthetic concepts. Only by extracting the most essential, mature, and typical national characteristics in the tradition can the designers create a national indoor space atmosphere that meets the needs of the new era.

\section{CULTIVATING THE INNOVATIVE CONSCIOUSNESS OF INTERIOR DESIGN IN ETHNIC MINORITY AREAS}

The road of interior design innovation in ethnic minority areas is very difficult. The reason is the marginalization of ethnic minority areas and the relatively independent existence of ethnic minority settlements. The transportation convenience between its regions is poor, and although cultural resources are relatively abundant, the economy is poor, technology is backward, and cultural values are closed. After the reform and opening up, the modern Western design civilization invaded, and the lifeline of ethnic minority cultures was impacted. The construction crafts and construction techniques left behind in ethnic minority cultures are almost on the verge of extinction because they lack the versatility, standardability and standardization of Western design. The culture of ethnic minorities has obviously become a weak culture. This transformation of strong and weak identities has caused a huge shock to the issue of cultural identity, making it difficult for ethnic minority cultures to be continued and passed on. Interior design is a highly comprehensive discipline. When people's lifestyles, behavior habits, moral standards, and even design content, tools, and skills change, the cultural identity and identity behind it also change. Interior designers are also worried about whether projects with innovative consciousness and exploratory spirit can be accepted by the public. As a result, the interior space design of contemporary minority areas often adds a backward or empty, soulless core after copying the shell of foreign culture [3].

Although interior design in ethnic areas can learn from successful experiences in China and foreign countries and current existing design results, it should not be meaningless "copy" or "apply". The atmosphere rendered and formed by the sense of innovation is an indispensable factor in the interior design process. Interior design works in ethnic minority areas not only need to rationally 
process and use ethnic culture and local folklore, and inherit the local ethnic minority culture, but also give users a sense of elegance and unconventionalism. The shape of the surface, the contrast and harmony of colors, the texture and touch of the materials, etc., all contain the creation of the local ethnic minority culture by the interior designer. In ethnic minority areas, it is necessary to create indoor spaces that conform to the local ethnic characteristics. Under the premise of preserving the lifestyles, behaviors, and religious beliefs of the aboriginal people, the ethnic atmosphere should be enhanced, the ethnic style should be strengthened, and the gorgeous ethnic colors need to be coordinated to create a space that not only allows people to experience ethnic minority culture and national characteristics, but also meets people's pursuit of fashionable life. This will undoubtedly push the national interior design into the international fashion trend. How to cultivate students' sense of innovation in the process of interior design in ethnic minority areas is a new requirement for contemporary interior design education in promoting the construction of rural human settlements in China. In practical teaching, teachers can set specific design tasks for a certain region or a certain ethnic group, and encourage students to obtain cultural resources of ethnic minorities through multiple channels, and boldly imagine problems encountered in interior design and various solutions to problems. In the process of design training, in order to innovate interior design works, students can actively pay attention to the architectural styles, building components, furniture accessories, daily necessities, religious beliefs, festivals, clothing culture and other content of ethnic minorities, and extract the most representative ethnic groups from them. And they can combine with contemporary indoor space that can meet people's life needs, aesthetic requirements, and spiritual appeals, so as to create a novel and unique space atmosphere with strong ethnic minority characteristics.

Ethnic minority areas have inexhaustible and inexhaustible national cultural resources. They are the expression of specific artistic concepts of local ethnic minorities and the source of artistic creation and design innovation. Promoting the creative consciousness of students in design advocates the exploratory expression of national cultural resources in the interior space design with another design thinking, expression technique, and visual effect. The spirit of exploration is based on existing interior design-related knowledge and experience, and innovative solutions to new problems. Teachers not only need to train students to have a systematic knowledge structure system, deep cultural heritage, solid design skills, and agile thinking skills, but also to keep students curious, dare to ask questions in front of novel phenomena, and use ethnic minorities resources to boldly expand abstract thinking and image thinking, rational thinking and perceptual thinking, enter conceptual design through multiple thinking channels. Teachers can also teach students to use graphical analysis to run through each stage of design, to establish the final design result with a comparative and optimal thinking process, and to solve the new situations and new problems that may arise in the interior design of ethnic minority areas with ease [4].

\section{PARTICIPATING IN THE PRACTICE OF INTERIOR DESIGN IN MINORITY AREAS}

Interior design projects in ethnic minority areas are artistic expressions of ethnic minorities' specific aesthetic concepts. They contain profound and diverse cultural connotations, embody the specific aesthetic culture of ethnic minorities, and convey the mysterious and diverse ethnic taboo culture. They also reflect the beliefs of ethnic minority groups in religious culture, show the eternal totem culture of ethnic groups, and permeate the simple ecological culture of ethnic groups, which is quite different from general interior design projects. For example, the indoor space layout of the dwellings of the Bai people in Dali follows the pattern of "three squares, one Zhaobi (screen wall facing the gate of a house), four in five patios". Zhaobi is also the essence of the dwellings of Bai nationality in Dali. It not only plays the role of reducing wind speed and shielding wind and dust, but also integrates various decorative arts such as architectural art, sculpture art, painting art, and calligraphy art. The industrious and intelligent Bai people carry the animal and plant elements in the natural world, combined with aesthetic taste and aesthetic culture, in the wall decoration, and become the most recessive gene of the national aesthetic concept in the indoor space; The residential buildings of Wengding Village, Cangyuan County, Lincang County, Yunnan mainly use natural materials such as wood, bamboo and grass. There are three fire ponds for the main, guest, and ghost, and the entire indoor space is laid out with the main firepit as the center, showing a line-shaped arrangement. The space function mainly includes the living room, bedroom and 
balcony. The walls are hung with horned bull skulls and other mysterious religious cultural factors, which reflect the religious culture of the "Muyiji God" and the primitive religious culture of all living things. [5]

Teachers can teach theoretical design methods in the classroom, but they may not be able to allow students to apply design methods to design practice. Only by participating in interior design practices in minority areas, experiencing the minority culture personally, and deepening their full understanding of national culture, can the students truly inherit national culture for ethnic minority indoor spaces in design practice. Therefore, colleges and universities should implement the method of combining teaching and practice, cooperate closely with the government and design institutions, and provide students with a good "production, learning, and research" design and exchange platform [6]. They need to organize and plan interior design practices in ethnic minority areas to enable students to grasp market demand and improve design capabilities. This can not only solve the common problem of the disconnection between the theoretical knowledge and practice of the students in the classroom, but also constantly acquire new trends, new materials, new crafts, and new technologies, so that students can deeply understand the particularity of interior design in ethnic minority areas, and creatively apply ethnic minority culture to interior space design in ethnic minority areas.

\section{CONCLUSION}

China has achieved remarkable results in implementing the rural revitalization strategy. Villages, towns and villages in ethnic minority areas have improved their human settlements, and the interior design industries such as residential houses, homestays, and hotels in ethnic minority areas have entered a stage of rapid development. At the same time, due to the lack of professional interior design talents in ethnic minority areas, designers have weak design awareness of ethnic culture and weak independent innovation capabilities, which restricts the development of the interior design industry in ethnic minority areas. The establishment of interior design or environmental design majors in colleges and universities in minority areas should strengthen the cultivation of students to establish a systematic concept of interior design, explore the diverse ethnic cultures of minority areas, cultivate innovative awareness of innovation in interior design, participate in the activities of interior design practice in minority areas, and provide high-quality resources and platforms for teaching and scientific research activities, to cultivate a steady stream of outstanding design talents for the interior design industry in minority areas as far as possible.

\section{AUTHORS' CONTRIBUTIONS}

Jing Guo wrote the manuscript, Zhao $\mathrm{Xu}$ contributed to revising and editing.

\section{REFERENCES}

[1] Guo Jing, Xu Zhao, Thoughts on Cultivation of Soft Decoration Design Talents [A]. Environment.Design.Fashion (Papers of the 9th National Academy of Fine Arts Teaching Annual Conference of Architectural and Environmental Art Design Teachers) [C]. Beijing: China Building Industry Press, 2012: 96-99. (in Chinese)

[2] Zhu Liangwen, Value and Inheritance of Traditional Houses [M]. Beijing: China Building Industry Press, 2011. (in Chinese)

[3] Lu Dandan, Why the Originality of Chinese Design Is Missing [J]. Art Observation, 2013. 09. (in Chinese)

[4] Zheng Shuyang, Interior Design + Ideas and Projects [M]. Beijing: China Building Industry Press, 2016. (in Chinese)

[5] Shi Jie, Cultural Implication of Environmental Design of Cultural Industrial Park in Ethnic Areas [J]. Guizhou Ethnic Studies, 2019, 06. (in Chinese)

[6] Yang Dongjiang, Ren Yilin, etc. Research on the Development of China's Interior Design Education $[\mathrm{M}]$. Beijing: China Building Industry Press, 2019. (in Chinese) 